\title{
Brazilian Public Schools and COVID-19: a picture of an asynchrony between technology and teaching practices
}

\section{Escolas Públicas Brasileiras e COVID-19: um retrato de uma assincronia entre tecnologia e práticas de ensino}

\author{
Ana Carolina Carius ${ }^{1 *}$
}

\begin{abstract}
This paper analyzes the process of preparation of Brazilian schools in terms of technological infrastructure, considering that these schools were not, for the most part, prepared for the use of technological tools during the so-called remote education due to COVID-19 pandemic. In addition, the predominant remote pedagogical practices at the national level were evaluated and how difficulties inherent to this process were overcome. As a research methodology, a literature review was carried out focusing on Brazilian remote education experiences, in addition to quantitative infrastructural analysis, based on data from School Censuses (official data from the federal government) for the years 2019 and 2020. Concludes that there was investment in digital technology in Brazilian schools during 2020 and that pedagogical practices in the same year were conducted empirically, from different realities, observing the individual commitment and interest of students, families, teachers, and managers, it is still necessary to work hard so that digital culture is part of the educational environment.
\end{abstract}

Keywords: Teaching practices; Technological tools; Closure of schools; Remote education; Digital culture.

\section{RESUMO}

Este artigo analisa o processo de preparação das escolas brasileiras em termos de infraestrutura tecnológica, considerando que essas escolas não foram, em sua maioria, preparadas para o uso de ferramentas tecnológicas durante a chamada educação a distância devido à pandemia de COVID-19. Além disso, foram avaliadas as práticas pedagógicas a distância predominantes em nível nacional e como foram superadas as dificuldades inerentes a esse processo. Como metodologia de pesquisa, foi realizada uma revisão de literatura com foco nas experiências brasileiras de educação a distância, além de análise quantitativa de infraestrutura, com base em dados de Censos Escolares (dados oficiais do governo federal) para os anos de 2019 e 2020. Conclui-se que houve investimento em tecnologia digital nas escolas brasileiras durante 2020 e que as práticas pedagógicas no mesmo ano foram realizadas de forma empírica, a partir de diferentes realidades, observando o comprometimento e interesse individual de alunos, famílias, professores e gestores, mas ainda é preciso trabalhar muito para que a cultura digital faz parte do ambiente educacional.

Palavras-chave: Práticas pedagógicas; Ferramentas tecnológicas; Fechamento das escolas; Ensino remoto; Cultura digital.

\footnotetext{
${ }^{1}$ Universidade Católica de Petrópolis.

*E-mail: ana.carius@ucp.br
} 


\section{INTRODUCTION}

March 13, 2020 marked the closure of schools in Brazil as a strategy to fight the COVID-19 pandemic. It was believed that this closure would be, initially, for fifteen days, with an extension for another fifteen days. Due to the seriousness of the pandemic, at the end of the first month of closure of schools, reflections were started at national level, on a model of remote education ${ }^{2}$ that would serve Brazilian students, since face-to-face meetings could not be resumed (CARIUS, 2020a)

The Brazilian educational system is divided into public and private schools. In the universe of public schools, these are divided into municipal, state and federal. Brazil has 5570 municipalities, with 26 states plus the Federal District. In all, according to the 2020 School Census, 47295294 students are enrolled in Brazilian Basic Education. Therefore, any unilateral and generalist measure for Brazilian education is never enough, given the size of the country and the specificities of each region.

In general terms, Brazilian schools can be characterized as follows: private schools and federal schools have better infrastructure, both physical and in digital technologies, when compared to state and municipal schools. So, this group was able to better organize remote classes during school closings. Municipal schools are, in general, those that have a digital technological infrastructure that is below the other types of schools described.

Why were Brazilian schools not prepared for remote teaching mediated by digital technologies? This work focuses on this research question, considering the scenario of Brazilian schools in the moment immediately before the COVID-19 pandemic. To answer this research question, this paper aims to analyze Brazilian schools, from the point of view of digital technological infrastructure in the moment immediately before the pandemic, based on data from the 2019 School Census and the consequences this scenario for remote education during the pandemic. Carius (2020b) discusses the asynchrony between school and digital devices as a case study in a rural Brazilian school. This work signalizes a major and national problem in Brazil: the absence of a public politic for digital culture in Brazilian schools.

\footnotetext{
${ }^{2}$ For this work, the terminology remote education was chosen to designate the conglomerate of activities that were carried out, in different Brazilian states and municipalities, when schools were totally closed.
} 
Manuel Castells (2019) analyzed, at the end of the 20th century, the influence of internet advances on social relations. For the author, economic relations between nations, relations with work and education change as the internet proposes new ways of relating. In this sense, digital culture gains strength. Kenski (2018) presents digital culture as a term with diverse perspectives linked to innovations and advances in knowledge and their incorporation, provided using digital technologies and network connections to carry out new types of interaction, communication, sharing and action in society. The school is not oblivious to this process. However, in Brazilian schools, there is an anachronyms between the specific school culture, which is reproduced year after year, in resistance to the incorporations inherent to the advancement of digital culture. Therefore, the starting point of this research is this: the need to absorb digital culture in the school environment, personified in its main actors: students, teachers, family members and school managers.

\section{LITERATURE REVIEW}

Considering that the COVID-19 pandemic has been going on for almost two years and that, in Brazil, schools started the opening process in August 2021, research involving pedagogical practices during Remote Teaching were published. Therefore, this research begins with a literature review in Brazilian journals on education and the COVID-19 pandemic. The Google Scholar Platform was used as the basis for accessing the works, with the keywords: 'Education and COVID-19'.

In the first search with the keywords listed above, the Google Scholar platform returned 44100 works. As the objective of this research is to evaluate Basic Education in the COVID-19 pandemic, a new search was carried out with the keywords: 'Basic Education and COVID-19', returning 21,100 works. Finally, the keywords 'Basic Education, Pedagogical Practices, COVID-19' were used in the Google Scholar Platform, returning 10500 works.

After reading the abstracts and keywords of the journals indicated by the Platform, five works were chosen for analysis in this research, which are presented below, the research themes and perspectives of pedagogical practices indicated by the authors.

- Education and COVID-19: the of reinventing the school mediating learning 'primarily' by the TDIC

Cani, J. B. \& Sandrini, E. G. C. (2020) 
The authors analyze the implications of the emergency use of so-called digital information and communication technologies in remote pedagogical practices during school closings. As they developed research in digital technologies and education, the authors bring interesting data on the subject in the state of Espírito Santo, one of the 27 Brazilian states. In an investigation with 57 teachers before the pandemic period, divided into municipal, state, and federal systems, in the municipality of Colatina, in the state of Espírito Santo, $60 \%$ of teachers in the municipal system and $56 \%$ in the state system were classified as not being digitally technological. Considering this scenario, the authors classified the teachers in levels of proficiency in digital information and communication technologies and based on these criteria, sought to assess the pedagogical practices that each group could develop during remote education, appropriate to the level of proficiency of each profile.

- Terminological profusion in the denomination of basic education pedagogical practices during the COVID-19 pandemic

Will, D. E. M.; Cerny, R. Z; Espíndola, M. B.; Lottermann, J. (2021)

This work was chosen to compose this literature review for approaching a striking theme in the Brazilian scenario: the nomenclatures used to designate remote education. The authors carried out a search in official documents of the State Departments of Education. Legal documents - ordinances, opinions, resolutions - and guiding information published on the secretariats' websites, identified as official guidelines, were considered as sources of information. The documents are presented in a textual form; already the information takes the form of guides, manuals, notices, news, tutorials textual and audiovisual. The consultations were carried out on the 27 websites of the State Departments of Education and on 12 websites of the State Councils of Education, from March to October 2020. It is noteworthy that the State Departments of Education are responsible for the legislation for teaching in Brazilian municipal, state, and private schools. The variety of terms listed by the authors in the 27 Brazilian states is indicated below: off-site activities (Acre); Special Regime of Non-Attendance School Activities (Alagoas); Classes and activities outside the classroom (Amapá); Special regime of nonpresential classes (Amazonas); Curricular activities under special regime (Bahia); Remote Learning, distance/home activities, teaching strategies and remote learning monitoring, non-face to face classes (Ceará); Non-presential Pedagogical Activities (Espírito Santo); Non-face to face classes (Goiás); Off-site classes and off-site 
pedagogical activities (Maranhão); Non-face-to-face teaching activities (Mato Grosso); Complementary pedagogical activity (Mato Grosso do Sul); Non-face-to-face teaching activities (Minas Gerais); Non-face-to-face teaching activities (Pará); Special education regime (Paraíba); Off-site school activities, off-site classes, Distance Education (Paraná); Extracurricular activities mediated by non-presential technologies (Pernambuco); Nonpresential modality, non-presential teaching (Piauí); Remote Teaching, non-face-to-face school activities (Rio de Janeiro); Distance mode (Rio Grande do Norte); Home activities, non-face-to-face teaching activities (Rio Grande do Sul); Non-face to face classes (Rondônia); Non-face to face activities, Remote Learning (Roraima); Special regime of non-presential school activities, Remote Education (Santa Catarina); Distance Learning, technology-mediated education, distance classes (São Paulo); Non-face-to-face complementary educational activities; off-site school activities (Sergipe); Non-face to face activities (Tocantins); Remote Teaching; Mediated teaching (classes mediated by technology); Online teaching, hybrid activities, Remote Learning, non-presential pedagogical activities, non-presential activities, remote technologies (Federal District). From the variety of terms listed above, it is possible to observe that this plurality of definitions and understandings about pedagogical practices during the period of school closing contributed negatively to the development of skills and competences of Brazilian children and adolescents enrolled in the country's public and private systems.

\section{- Class at Home: education, digital technologies, and COVID-19 pandemic}

Santana, C. L. S. \& Sales, K. M. B. (2020)

The authors discuss a point common to other works listed in this literature review: the fragility of understanding what Distance Education or Online Learning is (from the perspective of the authors). The argument brought up by the authors is that physical social distancing transposed education to remote contexts without considering the pedagogical foundations of literature and research in Distance Education. The authors conclude that the pedagogical practices elected as predominant during the closing of schools, in addition to being ineffective about the quality of the training process, can compromise the path of building an institutional culture for the development of training processes in the modality at a distance in the post pandemic moment.

\section{- Basic education teachers in COVID-19 times}

Baade, J. H.; Gabiec, C. E.; Carneiro, F. K.; Micheluzz, S. C. P.; Meyer, P. A. R. (2020) 
The authors discuss the effects of the COVID-19 pandemic on the pedagogical practices of Brazilian basic education teachers. Considering as a starting point the absence of public policies that would encourage teacher training for the appropriation of pedagogical practices that involve digital technologies, the authors carried out a qualitative and quantitative research, distributing questionnaires to teachers, obtaining 272 responses from teachers. The research focused on the training and preparation of teachers in the moment immediately prior to the COVID-19 pandemic, verifying that these professionals were not prepared either from the point of view of knowledge or the digital infrastructure to carry out remote activities when schools closed. In addition, the use of the domestic space as a work area and the lack of boundaries between the two environments (home and work) contributed to teacher exhaustion during the period of remote education.

- Digital Culture and digital teaching resources: an overview of teaching during the COVID-19 pandemics

Nonato, E. M. R.; Sales, M. V. S.; Cavalcante, T. R. (2021)

The authors advocate the idea that digital culture, immersed in educational processes in an emergency way during the COVID-19 pandemic, can substantially modify pedagogical practices in the post-pandemic period. To support this hypothesis, the authors carried out a survey-type study with 502 teachers of basic education and higher education in public and private schools in the state of Bahia. The results collected by this research allowed the authors to state that, although there is still much to be done to ensure an effective digital enculturation in schools in Bahia, the balance of teachers' learning in relation to the use of TDIC in their practice is quite positive and creates a culture broth that, if well used, can accelerate the march of digital enculturation of the school.

From this literature review, it was intended to present a national panorama, documented in structured and published research, about the closing period of Brazilian schools. It appears from the results presented that the autonomy attributed by the Brazilian educational system to states and municipalities provided different proposals for remote education, adapted to different regional scenarios. However, points in common to the different realities are identified: lack of teacher training in digital technologies, so that pedagogical practices during remote education were, in fact, innovative and absence of digital technological infrastructure in public and private schools immediately before the 
pandemic, so that teachers and students were inserted in the digital culture and appropriated tools that were used ostensibly during it.

\section{RESEARCH METHODOLOGY}

Considering that social distancing is still in force in Brazil when this research was carried out, preference was given to a quantitative study based on official data from the Brazilian Ministry of Education. The School Census is a survey sent annually to Brazilian public and private schools. Therefore, this data source was used to validate the research question addressed in this work.

The unprecedented closing of schools due to the COVID-19 pandemic for an extremely prolonged period still gives the research an exploratory character, as there were, until then, no recent work with this focus. According to Antonio Carlos Gil (1999) 'the main purpose of exploratory research is to develop, clarify and modify concepts and ideas, with a view to forming more precise problems or researchable hypotheses for further studies.' As there is not, until then, a scientific panorama for Brazilian education systems, whether public (municipal, state, or federal) or private, about technological infrastructure, exploratory research is validated.

\section{RESULTS AND DISCUSSIONS}

As described above, this study is based on the last two School Censuses (2019 and 2020) carried out by the Ministry of Education in Brazilian public and private schools. We tried to list items from the questionnaire sent to schools related to the technological infrastructure of these educational establishments. Seven items from the questionnaires were analyzed, which are described below by sphere: private schools and public schools (municipal, state and federal).

\subsection{As for the availability of desktops for students}

In this section, it was evaluated whether Brazilian schools made desktops available to students for them to use during their stay in the school unit. In Figure 1 and Figure 2, the relative frequency of school units that had desktops for use by students in 2019 and 2020 was compared. 
Figure 1 - Availability of desktops for students (private and federal schools)

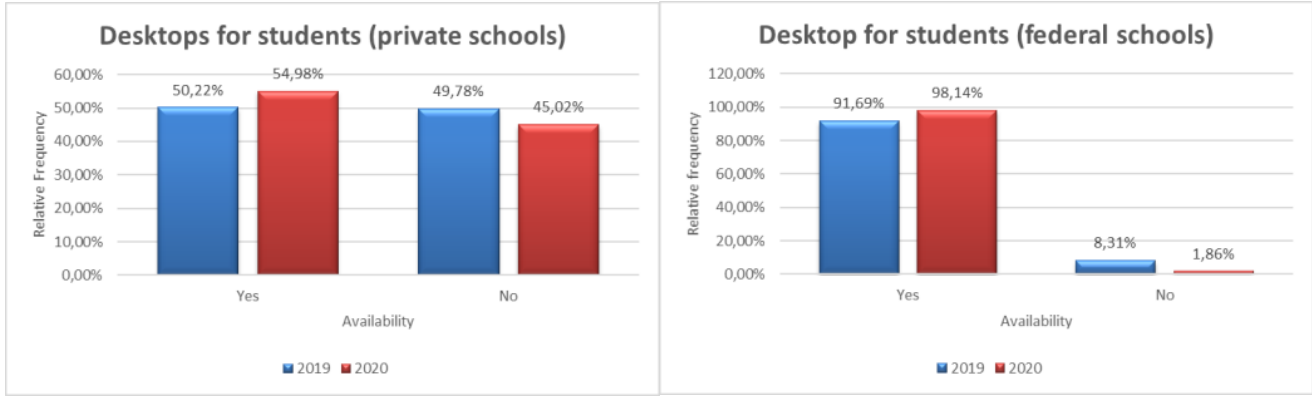

Fonte: Carius (2021).

Figure 2 - Availability of desktops for students (state and municipal schools)
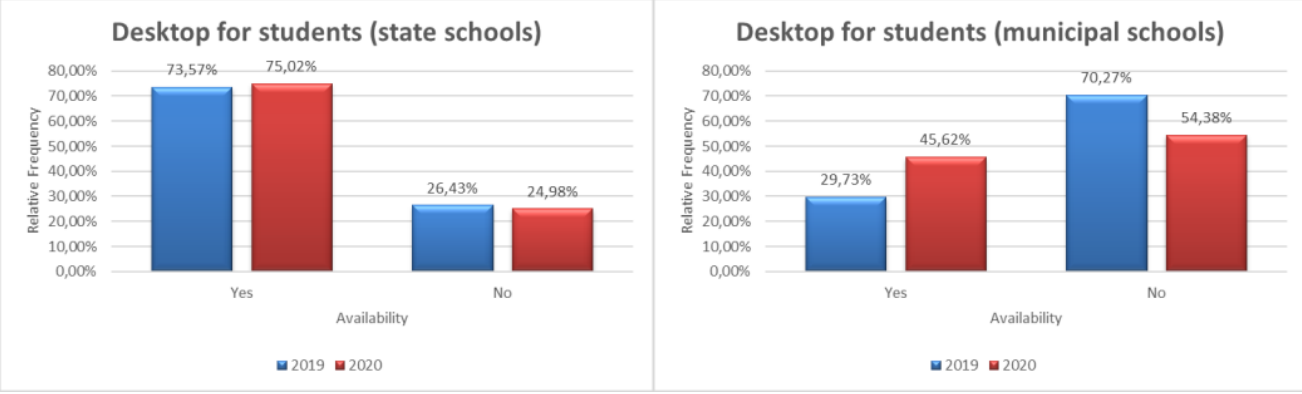

Fonte: Carius (2021).

It is observed that almost all schools in the federal education system have desktops for students to use. There was an increase in the availability of desktops for students in all education systems, with an emphasis on a significant increase in the municipal education system.

\subsection{As for the availability of notebooks for students}

In this section, the availability of notebooks for use by students in Brazilian schools during their stay at the school unit was evaluated. Figures 3 and 4 compare the relative frequency of notebook availability for student use in 2019 and 2020.

Figure 3 - Availability of notebooks for students (private and federal schools)

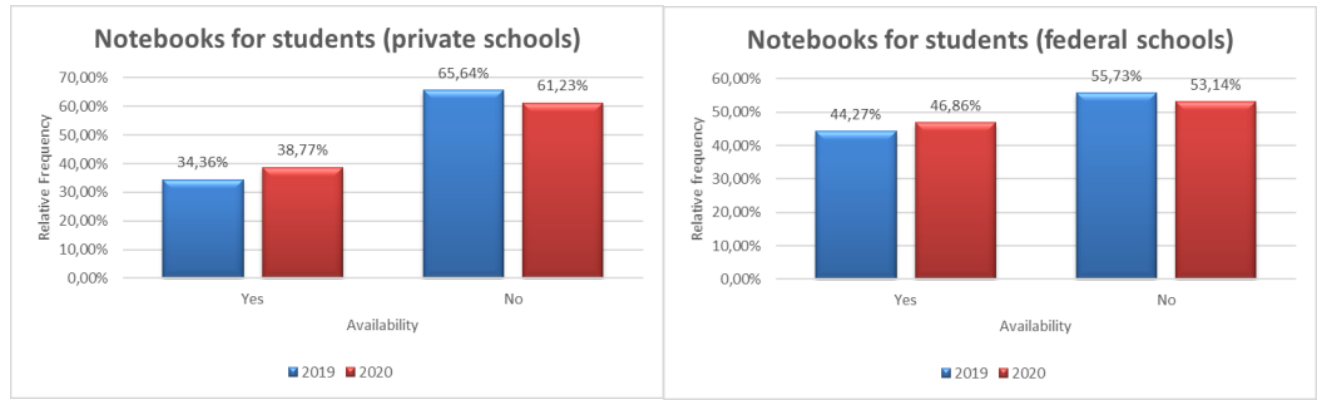

Fonte: Carius (2021). 
Figure 4 - Availability of notebooks for students (state and municipal schools)

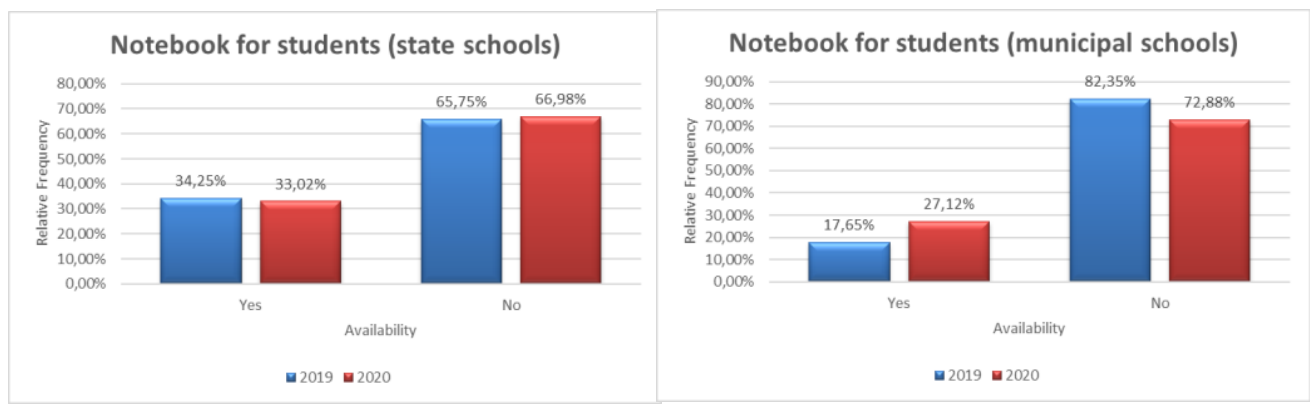

Fonte: Carius (2021).

For this category, it is observed, again, that the federal education system has more notebooks available for use by students than other education systems. Considering the comparison between the years 2019 and 2020, there was a greater proportional increase in the availability of notebooks in the municipal education system.

\subsection{As for the availability of tablets for students}

In this section, it was evaluated whether Brazilian schools made tablets available to students for them to use during their stay in the school unit. In Figure 5 and Figure 6, the relative frequency of school units that had tablets for use by students in 2019 and 2020 was compared.

Figure 5 - Availability of tablets for students (private and federal schools)

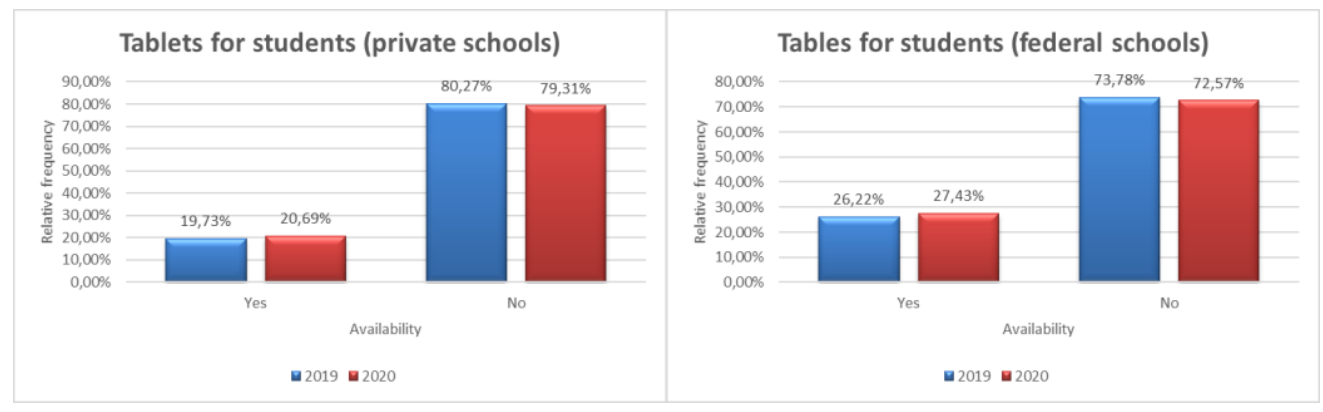

Fonte: Carius (2021).

Figure 6 - Availability of tablets for students (state and municipal schools)

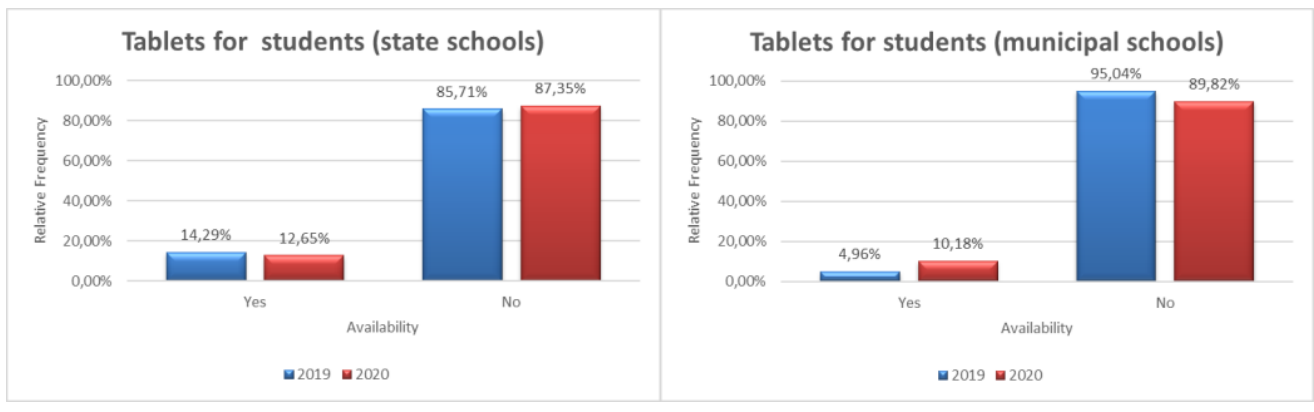

Fonte: Carius (2021). 
Considering tablets as a tool to access education via digital technologies, it is observed that these are not the preferred instruments in any of the education systems. In the case of the state education system, there was a decrease in the supply of tablets for students to use when comparing the years 2019 and 2020.

\subsection{As for the availability of internet for Brazilian schools}

In this section, the availability of internet for use in Brazilian schools was evaluated. Figures 7 and 8 compare the relative frequency of internet availability at Brazilian schools in 2019 and 2020.

The availability of internet in schools is one of the biggest problems when considering municipal education systems. It should be noted that these systems are responsible for providing education in the most distant places in Brazil. From the analysis carried out in this item, it can be observed that municipal schools are the ones that access the internet the least. However, comparing the access of municipal schools to the internet between 2019 and 2020, there was a substantial increase in internet access.

Figure 7 - Availability of internet in Brazilian schools (private and federal)

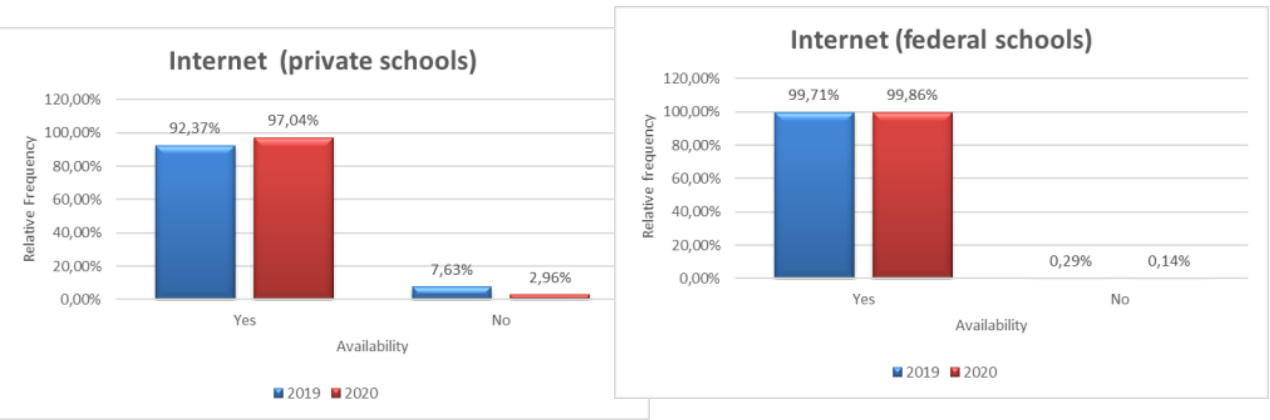

Fonte: Carius (2021).

Figure 8 - Availability of internet in Brazilian schools (state and municipal schools)

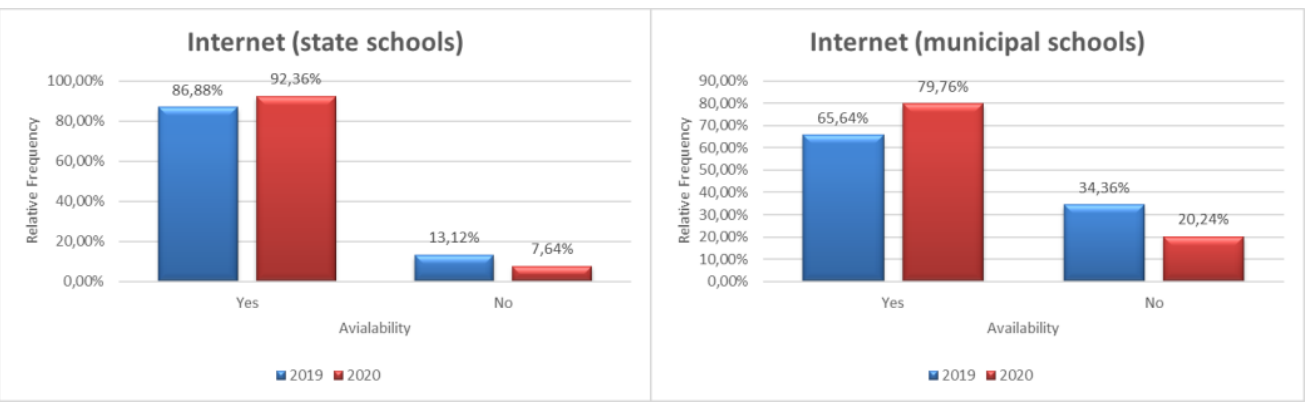

Fonte: Carius (2021). 


\subsection{As for the availability of internet for students}

In this section, the availability of internet for use by students in Brazilian schools during their stay at the school unit was evaluated. Figures 9 and 10 compare the relative frequency of internet availability for student use in 2019 and 2020.

Figure 9 - Availability of internet for Brazilian students at school (private and federal)

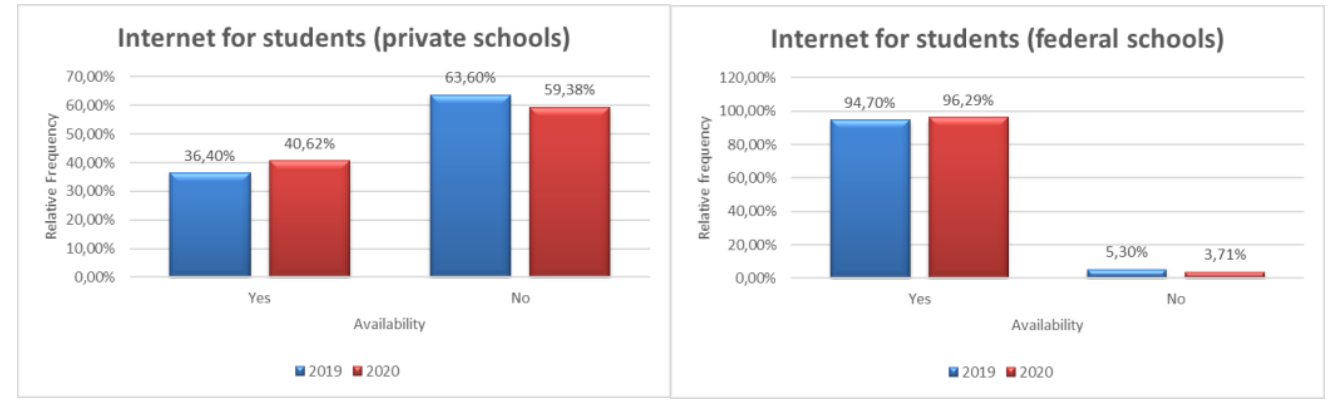

Fonte: Carius (2021).

Figure 10 - Availability of internet for Brazilian students at school (state and municipal)

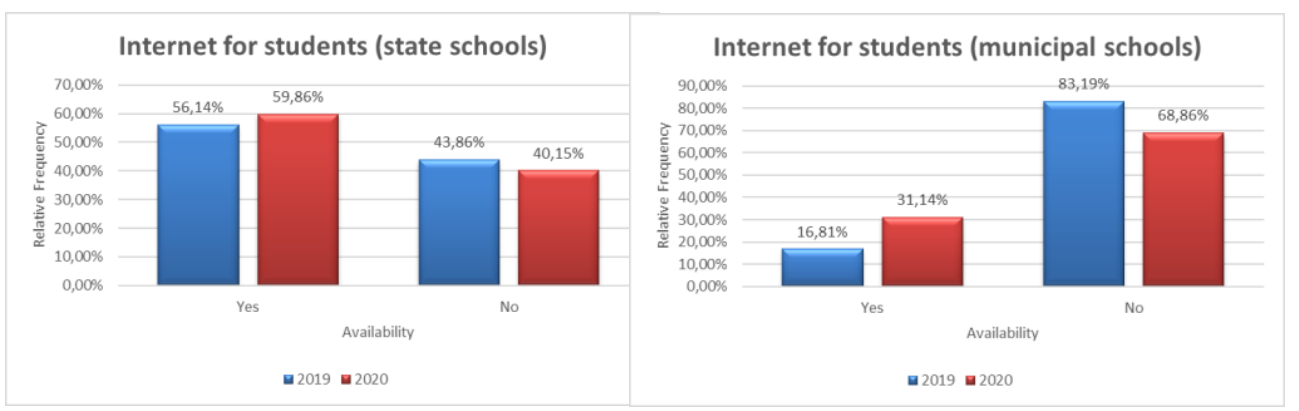

Fonte: Carius (2021).

This category was included in this research with the aim of raising the reflection on the need for the development of digital culture in Brazilian educational spaces. From the literature review presented in the previous section, the need for teacher training in the context of digital culture was observed, just as it is necessary to value it with students in the school environment. One of the aspects that reinforces the non-relevance of digital culture in the school environment is the access, by students in the physical environment of the school, to the internet. Only the federal education system values and provides internet access for students in its schools. In other education systems there is a not so close relationship between school access to the internet and internet access by students in the school environment. This relationship reflected negatively during the COVID-19 pandemic: when considering the internet as part of the tools necessary for the development of classes remotely, skills and competences were not developed for the 
actors involved in the teaching-learning process so that everyone was prepared for this moment. From the data in Figures 9 and 10, it is observed that the municipal education system is still the one that least encourages students to access the internet on school premises.

\subsection{As for the availability of Internet for personal devices}

The last analysis presented in this work refers to the availability of internet access for personal devices in the physical premises of Brazilian schools. Figures 11 and 12 show the availability of internet for individual access by personal devices in Brazilian schools.

Figure 11 - Availability of internet access for personal devices (private and federal)

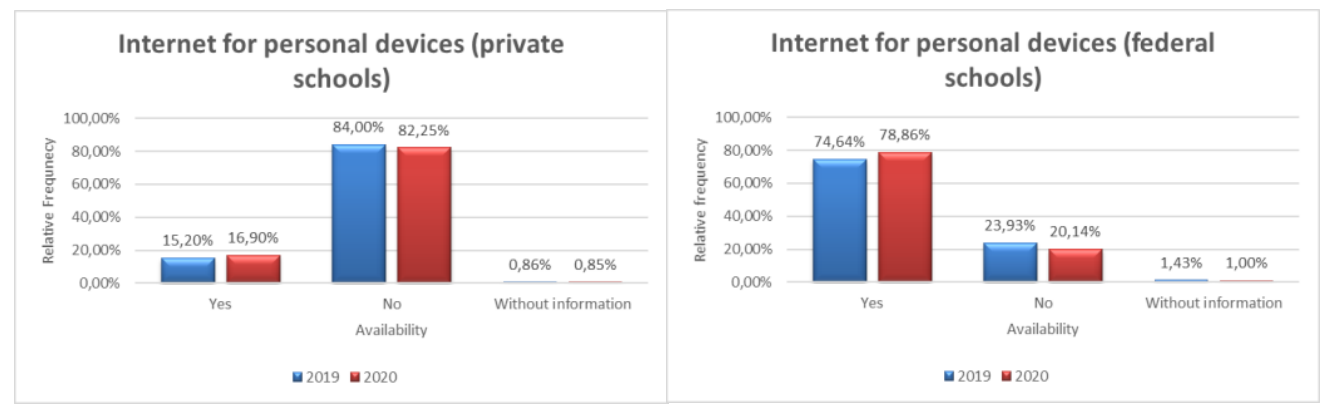

Fonte: Carius (2021).

Figure 12 - Availability of internet access for personal devices (state and municipal)

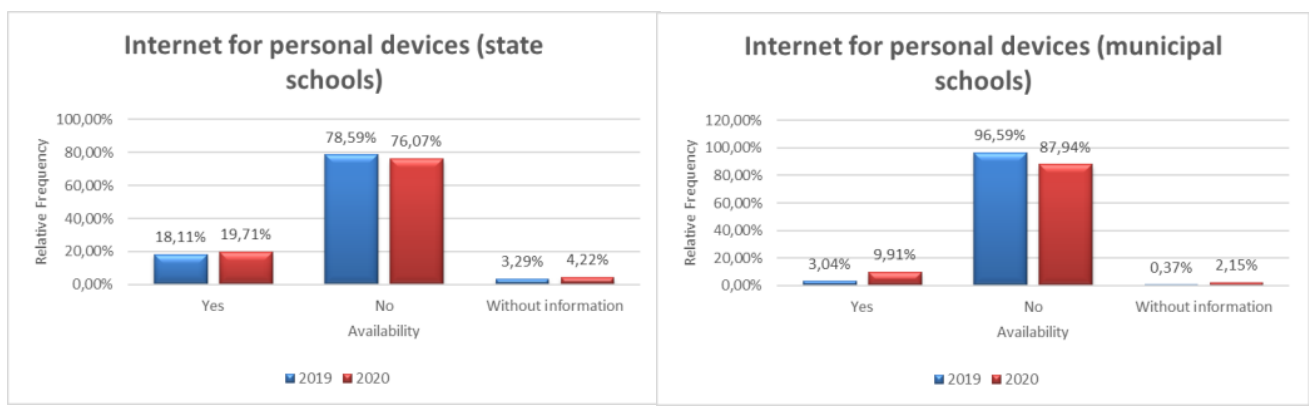

Fonte: Carius (2021).

The last theme proposed in this research refers to internet access for personal devices, whether these belong to students, teachers, managers or administrative employees. As described in section 4.5 , there is an absence of digital culture in the physical environment of schools, as mobile devices in general do not have access to the internet. This aspect stands out when compared with information from the literature review regarding the way school activities were conducted remotely during the closing of schools. On that occasion, mainly students from the municipal and state education systems were invited to use their smartphones to monitor teaching activities. Teachers, 
students, their families and school managers had to incorporate, in a short period of time, digital skills and competences that were not previously developed in the school environment in order to carry out the pedagogical practices. The data listed in Figures 11 and 12 show the asynchrony between the use of mobile devices with internet access in the school environment and their use during remote education developed in COVID-19 pandemic.

\section{CONCLUSION}

The present work aimed to present an overview of how education occurred during the COVID-19 pandemic in Brazilian schools, to answer the research question: 'Why were Brazilian schools not prepared for remote teaching mediated by digital technologies?'

Considering the literature review presented, it was possible to observe that remote education occurred in different ways, depending on the state guidelines sent in each of the 27 Brazilian states. However, some common perspectives were listed, namely: the absence of digital culture in the educational environment, a fact that made it difficult to carry out remote pedagogical practices; lack of development of digital skills and competences, both for teachers and students, so that pedagogical practices mediated by digital technologies would not represent a challenge, in addition to the health, psychological, economic and social challenges that the COVID-19 pandemic itself represented and asynchrony between pedagogical practices involving digital technologies with the perspective of Brazilian schools.

To validate the asynchrony between digital technologies and pedagogical practices during the COVID-19 pandemic in Brazil, data from the School Census was used, an important survey developed by the Ministry of Education in Brazil, with relevant information on digital technologies in schools. From this survey, it was possible to assess that there was some investment in digital technological tools between the years 2019 and 2020. This fact is considered positive, as it denotes that the experience of the ostensible use of digital technologies during the closing of schools signalled the importance of having adequate technological tools so that innovative pedagogical practices can be developed in schools after the pandemic.

Although data from the School Census demonstrate the fragility of Brazilian education systems about digital technologies, with emphasis on the municipal education 
system, considered the most fragile in this regard, while, due to its 'capillarity', it affects the more distant regions of the country. For this education system, the presence of activities on paper predominated, with the distance education through physical handouts being preferred.

For the other education systems (state, federal and private), the use of synchronous classes (Google Meet, Zoom or Microsoft Teams) together with asynchronous activities (recorded videos, handouts, exercises) were the predominant pedagogical practices. Experiences of pedagogical practices considered innovative, such as the use of active methodologies or the so-called blended learning, cannot be considered as predominant in the pedagogical models adopted. What was noticed were traditional pedagogical practices, related to industrial and massive teaching, as predominant, in which digital technological tools only helped teachers to carry out pedagogical practices traditionally established in face-to-face education. This fact reinforces the teacher as a consumer of digital technologies, in an environment where digital culture still needs to be developed.

Finally, the perception that the internet is not ostensibly available in Brazilian schools, just as access to the internet is limited in thousands of educational establishments, whether for use on mobile devices or for educational purposes, demonstrates that there is a long way to go. Indeed, for experiences involving digital technologies during the pandemic to become important motivations for the inclusion of digital culture in Brazilian education, it is urgently necessary to assess the asynchrony between digital technologies and current pedagogical practices.

\section{REFERENCES}

BAADE, J. H.; GABIEC, C. E.; CARNEIRO, F. K.; MICHELUZZ, S. C. P. e MEYER, P. A. R. Basic education teachers in COVID-19 times. Holos, v.5, e10901, 2020. https://doi.org/ 10.15628/holos.2020.10910.

CANI, J. B.; SANDRINI, E. G. C.; SOARES, G. M. e SCALZER, K. Education and COVID-19: the of reinventing the school mediating learning 'primarily' by the TDIC, Revista Ifes Ciência, v.6, n.1, p.23-29, 2020. https: //doi.org/10.36524/ric.v6i1.713.

CARIUS, A. C. Network Education and Blended Learning: Cyber University concept and Higher Education post COVID-19 Pandemic, Research, Society and Development, v.9, n.10, e8209109340, 2020a. http://dx.doi.org/10.33448/rsdv9i10.9340. 
CARIUS, A. C. Teaching Practices in Mathematics During COVID-19 Pandemic: Challenges for Technological Inclusion in a Rural Brazilian School, American Scientific Research Journal for Engineering, Technology, and Sciences (ASRJETS), v.7, n.1, p.35-43, 2020 b.

CASTELLS, M. A sociedade em rede. 20a edição. Editora Paz e Terra, 2019.

KENSKI, V. Cultura Digital. In D. Mill (Eds.), Dicionário Crítico de Educação e Tecnologias e de Educação a Distância (pp. 139 - 143). Papirus, 2018.

NONATO, E. M. R.; SALES, M. V. S.; CAVALCANTE, T. R. Digital Culture and digital teaching resources: an overview of teaching during the COVID-19 pandemics. Revista Práxis Educacional. v.17, n.45, p.1-25, 2021.

https://doi.org/10.22481/praxisedu.v17i45.8309

SANTANA, C. L. S. e SALES, K. M. B. Class at Home: education, digital technologies, and COVID-19 pandemic. Interfaces Científicas, v.10, n.1, p.75-92, 2020. https://doi.org/10.17564/2316-3828.2020v10n1p75-92

WILL, D. E. M.; CERNY, R. Z.; ESPÍNDOLA, M. B. e LOTTERMAN, J. Terminological profusion in the denomination of basic education pedagogical practices during the COVID-19 pandemic. Em Rede: Revista de Educação a Distância, v.8, n.1, 2021. https://doi.org/10.53628/emrede.v8.1.726 